\title{
Employee Performance Improvement Models
}

\author{
Mei Rista Rahmasari ${ }^{\bowtie}$, Nury Ariani Wulansari \\ Management Department, Faculty of Economics, Universitas Negeri Semarang, Semarang, Indonesia
}

\author{
Article Information \\ Article History: \\ Received January 2020 \\ Approved February 2020 \\ Published March 2020

\section{Keywords:} \\ Emotional Intelligence, \\ Deep Acting, Surface \\ Acting, Employee perfor- \\ mance.
}

\section{INTRODUCTION}

The development company engaged in service today's increasingly global and competitive. Competing businesses increasingly stringent demands of companies have a competitive advantage in order to compete and maintain its existence (Manurung et al., 2016), Quality of human resources and potentially able to take the company to win the competition of globalization so that it can be said that HR is a major factor in determining the success of the company. Every organization must have a strategy to be able to retain employees who are quality (Raharjo \& Witiastuti, 2016). Therefore, within an organization, HR becomes an important and valuable asset in determining the performance of the organization (Susmiati \& Sudarma, 2015; Batarliene et al., 2017; Latifah \& Wulansari, 2017).
The success of a company is strongly influenced by the performance of the individual, therefore every company is always trying to improve employee performance to achieve the goals set. If the individual within the company as human resources can work effectively then the company can work effectively (Ranihusna, 2010). Performance should be supported by a reliable employee quality, professional competence and adequate because they play an important role in interacting with customers. Thus, HR is the most important factor for creating excellence that can not be easily imitated by competitors for each organization (Ariasti \& Wulansari, 2017). In research of Imawati and Amalia (2011) explained that the success of the company is supported by the state and the quality of its human resources. One indicator of this problem is job perfomance or commonly called the performance (Salanova et al., 2005).

(C) 2019 Universitas Negeri Semarang

\footnotetext{
Correspondence Address:

L2 Building, 1st Floor, Faculty of Economics, Universitas Negeri Semarang

Jalan Taman Siswa, Sekaran, Gunungpati, Semarang, 50229

E-mail: meirista1326@gmail.com
} 
Performance is still a problem often faced by the management, so that management needs to determine the factors that affect the performance of the employee (Fitriastuti, 2013). Employee performance is influenced by a variety of factors, both internal factors in each of the employees as well as external factors, namely the work environment (Joushan, Syamsun, \& Kartika, 2015). One important factor in determining the performance of that sense of work engagement of each employee.

Work engagement has become an issue which is quite often observed in the corporate environment. Data from the survey by Gallup, found that the level of work engagement since the year 2000 - 2016 states that $87 \%$ of people worldwide do not have a good working attachment to the company where they work. Likewise in 2017 who did not experience a significant change is reduced to $85 \%$. While in Indonesia alone in 2016 , said the level of attachment to work only $8 \%$ is owned by employees only. This is an issue that is interesting to note because the level of employee engagement affects productivity and performance of employees.

Theoretically, the work engagement affect the performance level of employees as in research Sarangi (2012) that employees who are bound to their work tend to have an attachment on the customer and encourages innovation in the work. Markos and Sridevi (2010) also presents the results of research that is consistent, that employee engagement is a strong predictor of the performance of the organization positively. Some other studies also showed similar results (Balducci et al., 2010; Karatepe, 2011; Bakker et al., 2012). Thus there is empirical evidence to show that the work engagement capable of affecting the performance of employees. However, there are also the results of previous empirical studies show inconsistent results.

In addition to employee engagement, employee-owned emotional intelligence is also a determining factor in performance. Employees who have skills in emotional intelligence will be able to read the feelings of others and have social skills means being able to manage other people's feelings very well. Emotional intelligence is crucial possessed by every employee in the company that will help employees dealing with other employees and share information as well as to manage the problems that arise in implementing the tasks in the job (Marpaung \& Rumondang, 2013).

An employee who has good emotional intelligence, apparently not only able to improve performance, but also can reduce work stress (Sanjaya, 2012). The existence of a good emotional management, then conflicts can be resolved pro- perly due to a conflict can be controlled and directed in the positive as regards the tasks assigned supervisor rather than as a burden, but a challenge that will bring change and development. Goleman (2000) through the research say that emotional intelligence accounts for $80 \%$ of the determinants of success of a person while the other $20 \%$ is determined by intellectual ability.The quality of an employee's emotional intelligence need to be considered in order to improve performance. Research conducted Law et al. (2008) suggests that there is a positive influence on the performance of the employee's emotional intelligence. Similarly, the results of research and Munir Azam (2017), which proves that emotional intelligence can improve employee performance, so that emotionally intelligent company needs to narrow the differences between the values of the spoken and values that run. Research conducted (Khanifah \& Palupiningdyah, 2015) also shows that emotional intelligence has a positive effect on performance. The results of this study indicate that the higher the emotional intelligence of employees, the higher the performance of employees. (Sosik \& Megerian, 1999).

In a previous study, it was mentioned that the emotional labor or emotion workers can also affect employee performance. Employees who work in the service sector, in doing his job always involves personal feelings and expression of emotions that both of these unwitting effect on the intent and attitude displayed by the employees (Keltner \& Haidt, 1999). Therefore, to meet these aspects, the work of employees should be able to regulate its emotional state (Grandey, 2000).

Emotions labor can be considered as one of the critical aspects of the few jobs that interact directly with the customer, which is expected to show emotion as expected the company, such as happy, enthusiastic; and hide the emotion of anger when working to fit the job requirements and expectations of the company (Groth et al., 2009). The fundamental purpose of service of employees to customers is to make the interaction more warm and friendly, but it prevents boredom and frustration (Kinman, 2008). In Hwa (2009) research results, it is stated that the emotional labor can improve service quality, customer loyalty, financial gain, his own employee job satisfaction, as well as emotional exhaustion, organizational commitment, and turnover intention.

Emotions labor has two dimensions, namely deep acting and surface acting. In a study of Judge et al. (2009) found that the surface has the effect of acting even more disturbing than the deep-acting employee welfare. Emotional changes produce adverse effects such employees make 
employees become more passive and may degrade performance (Baumeister et al., 1998). Previous research conducted by Grandey (2003) states that there is a direct influence of the variables of emotional labor and employee performance, which is a positive relationship significant occurred in the dimension of deep acting on employee performance, while negative relationships were significant on the dimensions of surface acting on employee performance (Liu et al., 2013). However, the research Goodwin et al. (2011) mentions that deep acting and surface acting does not affect performance significantly.

Based on the interview with the head of the service and some employees of the insurance company owned enterprises in the city of Semarang on May 14 untill May 23, 2018, obtained information that the state-owned insurance companies are always trying to improve its performance to provide the best service. One of them, the number of successful claims settled by insurance company employees at state-owned companies in the city of Semarang indicates a rise in the number of cases the settlement of claims over the last three years.

Based on the description of the background of the above problems, the authors are interested in doing research with the title "Employee Performance Improvement Models"

\section{Hypothesis Development}

Employee engagement is particularly important when companies want their employees to contribute fully to achieve the target set by the company. Working attachment greatly affect the performance of individuals within the company (Abed \& Hebashy, 2016). Employee engagement have characteristics include Vigor (characterized by high energy level and mental toughness when it works, as well as a desire to give effort to the job, as well as resilience in the face of adversity), Dedication (characterized by enthusiasm, inspiration, pride and challenge), and Absorption (characterized by concentrating full and happy when engaged in the work, so that time will be felt running quickly even if an employee is in trouble) (Schaufeli \& Bakker, 2004). Employees who have a high work engagement with a passion for work, provide a real dedication in her work, as well as comfortable on the work carried out, will make a stand to be at work to finish the job as expected by the company. Conversely, if the employee does not have a high engagement to work, the employee will not work efficiently and will impact on the poor performance of employee. will make a stand to be at work to finish the job as expected by the company.
The influence of the working attachment on the performance conducted by previous researchers showed a positive relationship. This is in line with the results of research conducted by Balducci et al. (2010), Bakker et al. (2012), Jackson (2014), which states that the work engagement can significantly affect performance. This means that when employees feel attached to their work, then the employee will display works with maximum performance. It is also supported by the results of research conducted by Alessandri et al. (2015) states that the work engagement positively and significantly related to performance. This shows that the more tied employees to their work, the higher the resulting performance of employees.

$\mathrm{H} 1$ : Work engagement and significant positive effect on employee performance.

Employees with high emotional intelligence have self-awareness and self-control and know how to cope with negative emotions appropriately, so that the work is considered easier to open communication and lack of understanding of each other (Rankin, 2013). Emotional intelligence is judged to have a positive psychological perspective. That is,employees who have high levels of emotional intelligence better, tend to be more skilled at calming himself quickly, have self-awareness, more skilled in focus, better in dealing with others and more adept at understanding others, so she will be able to complete the entire work load without excessive stress. Furthermore, emotional intelligence also makes employees have the ability to motivate yourself and stay motivated to face the difficulties that may be encountered that has to do with the performance of an employee in the company.

Many studies have proven that employees who have a high level of emotional intelligence that will result in better performance Wong \& Law (2007); Ali (2013) with the performance appraisal based on the task and contextual performance. Cherniss (2000:) also revealed that although an employee's performance is quite good, but if the employee has a closed nature, not bernteraksi with others, as well as the management of other emotions as well the performance of the employee can not develop. Performance is related to the quality of services provided. For High-performance employees will be able to provide excellent service (Sudarma, 2012).

$\mathrm{H} 2$ : Emotional intelligence and significant positive effect on employee performance.

Basically, the emotional labor required to guarantee the employee's emotional expression 
to regulate the behavior of employees ( $\mathrm{Chu} \&$ Murrmann 2006). In the application of emotional labor, it turns deep acting is indispensable in regulating the display of emotion on the customer to be positive, as enthusiastic, cheerful, excitement, friendly, and attentive to customers. In addition, a person's emotional expressions can influence the emotions of others. So, with deep acting can enhance interpersonal interactions between employees and customers in conveying information about what he is feeling, desire, and the position of someone who express emotion.

Deep acting which is the expectations of the organization can have an impact on the taste of the results of the performance of the employee, because to maintain the quality of service for the company that is constantly evolving need employees who have working attitude proactive, initiative, responsibility to continue to develop, make, full of energy and is tied to his work (Bakker et al., 2011). So that the work expected of employees do not feel pressure and stress can interfere with performance. Research conducted by Liu et al. (2013) states that deep acting positive and significant effect on the employee's performance in the Chinese restaurant. In harmony with this, research conducted by Grandey (2003) also states that deep acting positively related to employee performance for employees who engage in deep acting would focus largely cognitive resources in completing the work. Based on empirical evidence from previous studies explain that deep acting positively related to employee performance.

H3: Deep Acting positive and significant effect on the performance of employees.

Surface acting described as a process of expressing emotions that are not perceived, by showing emotion required under the demands of work (Diefendorff et al., 2005). Thus, surface acting happens when an employee does not modify emotions in accordance with personal circumstances of employees by holding true feelings felt. When employees are displaying surface acting, in fact he suffered emotional dissonance because the difference between an expression and inner feelings that can lead to decreased performance achieved the employees. It also can lead to increased emotional exhaustion (Brotheridge \& Grandey, 2002).

Employees are required to provide the best service to the customer, where the demands of employees and differences in the characteristics of customers also creates pressure of its own, so often associated with job stress originating from the low autonomy, feeling unsafe with the number of customers and the demands of the job are con- stantly in need of a solution troubleshooting able to cause depression, psychosomatic, absenteism, declining morale and dedication of the employees on the job you have, even the desire to leave the job (Burke et al., 2012).

Richard and Gross (2000) reveals that the surface acting requires employees to invest more cognitive resources and power to manipulate the expression of views which will be shown where it can interfere with cognitive performance of employees with regard to thinking of creative ideas in his work. In this regard, a study done by Grandey (2003) shows that there is negative and significant impact on employee performance surface acting. In harmony with this, a study conducted by Liu et al. (2013) explains that employees who play a surface acting in the course of work will have very little energy to invest in demonstrating the performance. As a result, employees who are frequently involved in acting surface tends to show a lower level of performance. Based on empirical evidence from previous studies explain that the acting surface has a negative correlation to the performance of employees.

H4: Surface acting significant negative effect on the working attachment.

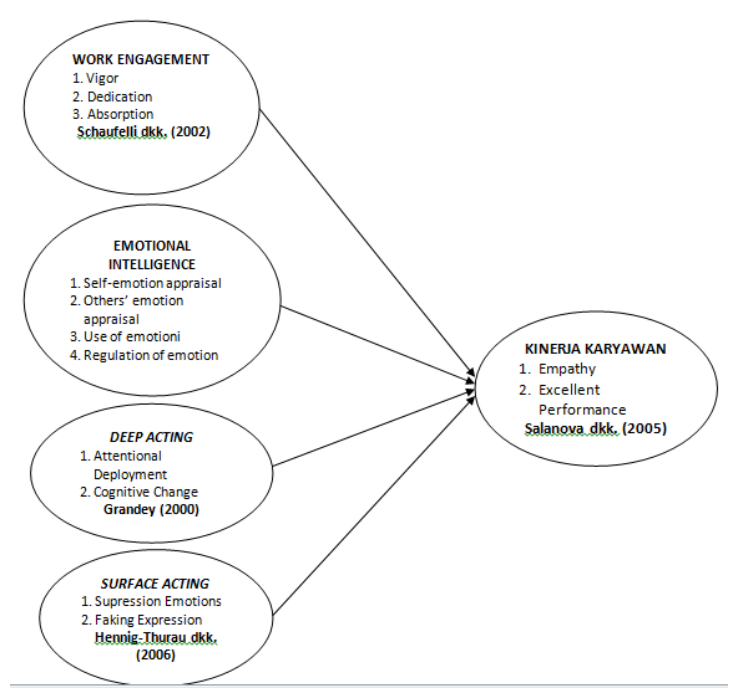

Figure 1. Research Model

\section{METHOD}

The population in this study are employees insurance company in Semarang, namely PT. Asuransi Jasa Indonesia (Persero) Semarang, PT. Jasa Raharja (Persero) Jawa Tengah, PT. TASPEN (Persero) Semarang, and PT. Asuransi Jiwasraya (Persero) Semarang. Total sample of this research were 121 respondents were obtained using the technique of saturated samples.

Methods of data collection using a questionnaire with Likert scale of 1-5 and an inter- 
view with the head of service. Emotional intelligence variables measured with 15 items of the statement of Wong \& Law (2002); acting deep variables measured by 4 items statement, whereas surface acting with 5 items from the second statement Diefendorff et al. (2005), In addition, the working attachment variables measured by the 15 items of the statement by Schaufeli et al. (2002) and variable employee performance is measured by item 6 of the statement by Salanova et al. (2005)

Feasibility test instrument used in this study was to test the validity and reliability testing. While the classical assumption used in this study is the normality test, multicollinearity, and heteroscedasticity test. Testing the hypothesis through partial test (test statistic $t$ ). Methods of analysis of this study used the software of SPSS version 21.

\section{RESULT AND DISCUSSION}

\section{Validity of Test Results}

Test the validity of the statement made on 45 items, of which emotional intelligence variables consisted of 15 statements, deep acting consists of 4 items statement, surface acting consists of 5 items statement, the working attachment consists of 15 statements, and employee performance consists of 6 statement. The number of respondents in the validity of the test as many as 121 respondents in order to obtain the value of $r$ table 0,179 . A questionnaire considered valid if it has a value greater than the count $r \mathrm{r}$ table. Based on tests of 45 items item question is known that all items that meet the criteria statement that the value of $r$ count $>r$ table (0.179), which indicates the item is valid declaration of variables.

\section{Reliability Test Results}

Based on reliability testing that has been done in this study indicate that all the variables have a value of croanbach alpha each variable $>$ 0.70 so that all the instruments in this study revealed reliable.

\section{Classical Assumption Test Results}

Normality test used to determine whether the regression model, or residual confounding variables have a normal distribution of (Ghozali, 2013), Statistical tests performed to test the residual normality in this research that non-parametric statistical tests Kolmogorov-Smirnov (KS). If the value of Kolmogorov-Smirnov more than $\alpha=$ 0.05 then the normal distribution of data. It can be seen that the value of the normality test using one sample Kolmogorov-Smirnov test, the value Asymp. Sig (2-tailed) is greater than the probability value is $0.995>0.05$, which indicates that the data are normally distributed Residual unstandardized.

\section{Test Results Multicollinearity}

Multicoloniarity test aims to test whether the regression model found a correlation between independent variables (independent) (Ghozali, 2013), A good regression model should not happen correlation between independent variables. Based multikolinearitas testing was done using SPSS version 21 obtained the result that all the variables have a value of Tolerance $>0.1$ and value Variance Inflation Factor (VIF) under 10. Therefore, it can be concluded that the regression model in this study did not happen multicollinearity between independent variables.

\section{Test Results Heteroskedastity}

Heterokedastisitas test aims to test whether the regression model occurred inequality variance from residuals of the observations to other observations. If variance from residuals of the observations to other observations remain, it is called and if different homokedastisitas called heterokedastisitas (Ghozali, 2013), Test heterokedastisitas in this peneilitian using glejser test. Glejser test results showed that all the variables have a significance level of $>0.05$, it can be concluded that there is no regression model heterokedastisitas.

\section{Hypothesis testing \\ Test Statistic $t$}

$\mathrm{T}$ statistical test used to indicate how far the influence of the explanatory variables / independent individually in explaining the variation of the dependent variable (Ghozali, 2013).

Table 1. Results of Test T Influence Work engagement, Emotional Intelligence, Deep Acting, and Surface Acting on Employee Performance

\begin{tabular}{cccccc}
\multicolumn{7}{c}{ Coefficients $^{\mathrm{a}}$} \\
\hline \multirow{2}{*}{ Model } & $\begin{array}{c}\text { Unstandardized } \\
\text { Coefficients }\end{array}$ & $\begin{array}{c}\text { Standardized } \\
\text { Coefficients }\end{array}$ & \multirow{2}{*}{$\mathrm{t}$} & \multirow{2}{*}{ Sig. } \\
\cline { 2 - 5 } & $\mathrm{B}$ & $\begin{array}{c}\text { Std. } \\
\text { Error }\end{array}$ & Beta & & \\
\hline (Constant) & 7.004 & 1.802 & & 3.886 & .000 \\
\hline El & .114 & .038 & .259 & 3.009 & .003 \\
\hline DA & .160 & .093 & .139 & 1.726 & .087 \\
\hline SA & -.138 & .064 & -.144 & -2.148 & .034 \\
\hline WE & .173 & .028 & .493 & 6.104 & .000 \\
\hline a. DependentVariable:TOT_EP & & &
\end{tabular}

According to the table above, obtained by calculation as follows that the independent variable work engagement has a $t$ value of 6.104 with 0.000 significance level $<0.05$. This means that the work engagement $\mathrm{H} 1$ stating a positive 
and significant effect on the performance of the employees received.

The independent variable of emotional intelligence has a t value of 3.009 with 0.003 significance level $<0.05$. This means that states of emotional intelligence $\mathrm{H} 2$ positive and significant effect on the performance of the employees received.

The independent variable of deep acting has a t value of 1.726 with a significant level of $0.087>0.05$. This means that deep acting $\mathrm{H} 3$ stating significant effect on the performance of employees rejected.

The independent variable surface acting has a $t$ value of -2.148 with a significant level of $0.034<0.05$. This means that states H4 surface acting as a negative and significant effect on the performance of the employees received.

Simultaneous Significance test (statistical test F)

Simultaneous hypothesis testing is intended to test the truth of influence together or simultaneous of independent variable on the dependent variable. Based on the results of research and calculations performed using SPSS 21 obtained the results listed in the table.

Table 2. Effect of Attachment F Test Work, Emotional Intelligence, Deep Acting, and Surface Acting on Employee Performance

\begin{tabular}{lccccc}
\multicolumn{6}{c}{ ANOVA $^{\mathrm{a}}$} \\
\hline Model & $\begin{array}{c}\text { Sum of } \\
\text { Squares }\end{array}$ & df & $\begin{array}{c}\text { Mean } \\
\text { Square }\end{array}$ & F & Sig. \\
\hline Regression & 316.478 & 4 & 79.119 & 34.488 & $.000^{\circ}$ \\
\hline Residual & 266.117 & 116 & 2.294 & & \\
\hline Total & 582.595 & 120 & & & \\
\hline a. DependentVariable: Employee Performance \\
\hline b. Predictors: (Constant), Work Engagement, Surface Acting, \\
Deep Acting, Emotional Intelligence
\end{tabular}

The above table shows the value Fhitung 34.488 with probability 0,000 . Since the probability of 0.0000 .05 , the regression model can be used to predict the performance of an employee or simultaneous attachment to work, emotional intelligence, deep acting and surface acting effect on employee performance and value models meet goodnes of fit.

Here is the formula used in the study:

$\mathrm{EP}=\mathrm{a}+\mathrm{b}_{1} \mathrm{WE}+\mathrm{b}_{2} \mathrm{EI}+\mathrm{b}_{3} \mathrm{DA}+\mathrm{b}_{4} \mathrm{SA}$

$\mathrm{EP}=7004+0.173 \mathrm{WE}+0.114 \mathrm{EI}+$

$0.160 \mathrm{DA}-0.138 \mathrm{SA}$

Information :

$\mathrm{EP}=$ Variable Employee performance

$\mathrm{a}=$ Constant

$\mathrm{b}=$ coefficient

$\mathrm{WE}=$ Variable Work Engagement
EI = Variable Emotional Intelligence

DA $=$ Variable Deep Acting

SA $=$ Variable Surface Acting

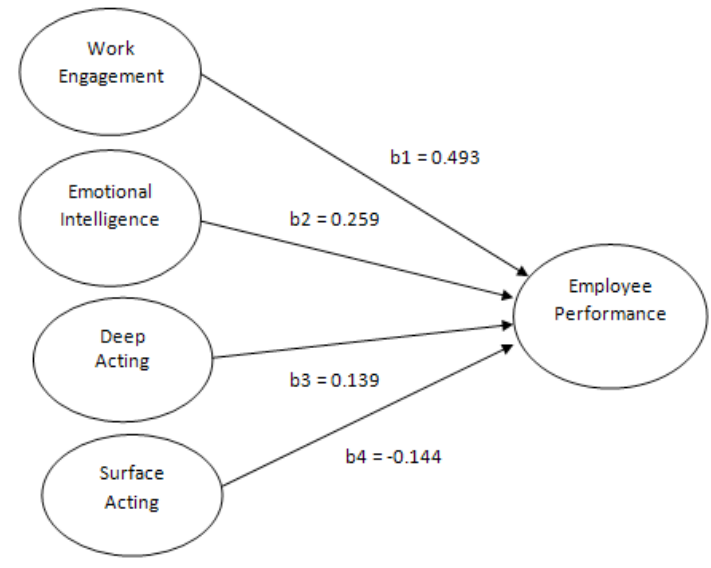

Figure 2. Result Model

\section{CONCLUSION AND RECOMMENDATION}

Based on data analysis and discussion of the research results, it can be concluded that the working attachment and emotional intelligence has a positive and significant impact on employee performance. While deep acting found to have no significant effect on performance, and surface acting alone can negatively and significantly on the performance of employees.

Research to be dating is expected to assess the emotional labor variables acting kususnya deep dimension that turns out to have a different effect and still need to do research on the same aspect to test the consistency of the results of this study. The results of this study can also be used as reference material for the foundations of the theory of how deep-acting effect on employee performance.

Future studies are also expected to develop the variables that can be influenced by deep acting and surface acting. In related research dimension of deep acting and surface acting is rarely examined other variables that may be affected and affects both the dimensions of emotional labor. The sample in this study used a sample of a service company in the area of insurance, then for further research are expected to do research on the company of other fields and can enlarge the sample, so that research results can be generalized.

Researchers suggest that the management of state-owned insurance company in Semarang can provide training in the proper handling of client in order to provide the basics in serving customers. Additionally, it creates an atmosphere 
that is comfortable working environment to support the expected emotions, also believes in openness in every meeting, briefieng, or other work activities in order to train the understanding of the way of thinking of others in every opinion which possessed. In addition, there are times when employees need to be given the task of working out which must be solved together as a team, so employees can better interact with others to train social life in the work environment.

Researchers suggest that the management of BUMN insurance company in Semarang can provide training in the proper handling of client in order to provide the basics in serving customers. The exercises given to employees also encourage employees to work harder. This is due to employees who have knowing well his duties and responsibilities will reach a moral level higher work. As for employees for a long time they also had to get training because of the demands of their duties now, or to prepare himself since it will be transferred or will promoted to another position (Rustiana, 2010). Additionally, it creates an atmosphere that is comfortable working environment to support the expected emotions, also believes in openness in every meeting, briefieng, or other work activities in order to train the understanding of the way of thinking of others in every opinion which possessed. In addition, there are times when employees need to be given the task of working out which must be solved together as a team, so employees can better interact with others to train social life in the work environment.

\section{REFERENCES}

Abed, F., \& Hebashy, A. (2016). The Relationship between Organizational Support, Work Engagement, and Organizational Citizenship Behavior as Perceived by Staff Nurses at Different Hospitals. Journal of Nursing and Health Science, 5(4), 113-123.

Alessandri, G., Borgogni, L., Schaufeli, W. B., Vittorio, G., \& Chiara, C. (2015). From Positive Orientation to Job Performance: The Role of Work Engagement and Self-Efficacy Beliefs. Journal of Happiness Studies, 16, 767-788.

Ali, Al Kahtani (2013). Employee Emotional Intelligence and Employee Performance in the Higher Education.

Ariasti, R. F., \& Wulansasri, N. A. (2017). Pengaruh Keadilan Prosedural pada Perilaku Kewargaan Organisasional melalui Komitmen Organisasi. Management Analysis Journal, 6(1), 67-75.

Bakker, A. B., Albrecht, S. L., \& Leiter, M. P. (2011). Key Questions Regarding Work Engagement. European Journal of Work and Organizational Psy- chology, 20(1), 4-28.

Bakker, M., van Dijk, A., \& Wicherts, J. M. (2012). The Rules of the Game Called Psychological Science. Perspectives on Psychological Science, 7(6), 543-554.

Balducci, C., Fraccaroli, F., \& Schaufeli, W. B. (2010). Psychometric Properties of the Italian Version of the Utrecht Work Engagement Scale (UWES-9): A Cross-Cultural Analysis. European Journal of Psychological Assessment, 26(2), 143-149.

Batarliene, N., Kristina, C., Kristina, V., Sapalait, I., \& Jarasuniene, A. (2017). The Impact of Human Resource Management on the Competitiveness of Transport Companies. Procedia Engineering, 187, 110-116.

Baumeister, R. E. F., Bratslavsky, E., Muraven, M., \& Tice, D. M. (1998). Ego Depletion: Is The Active Self a Limited Resource? Journal of Personality and Social Psychology, 74(3), 774-789.

Brotheridge, C. M., \& Grandey, A. A. (2002). Emotional Labor and Burnout: Comparing Two Perspectives of "PeopleWork." Journal of Vocational Behavior, 60(1), 17-39.

Burke, R. J., Koyuncu, M., \& Fiksenbaum, L. (2012). Hospital Culture, Work Satisfaction and Psychological Well-being among Nurses in Turkish Hospital. Europe's Journal of Psychology, 7(4), 624-639.

Cherniss, C. (2000). Emotional intelligence: What it is and why it matters. Paper presented at the Annual Meeting of the Society for Industrial and Organizational Psychology, New Orleans, LA, April 15, 2000.

Chu, K. H. L., \& Murrmann, S. K. (2006). Development and Validation of The Hospitality Emotional Labor Scale. Tourism Management, 27(6), 1181-1191.

Diefendorff, J. M., Croyle, M. H., \& Gosserand, R. H. (2005). The Dimensionality and Antecedents of Emotional Labor Strategies. Journal of Vocational Behavior, 66(2), 339-357.

Fitriastuti, Triana. (2013). Pengaruh Kecerdasan Emosional, Komitmen Organisasional dan Organizational Citizenship Behavior Terhadap Kinerja Karyawan. Jurnal Dinamika Manajemen, 4(2), 103-114.

Ghozali, I. (2013). Aplikasi Analisis Multivariate dengan IBM SPSS: 21. Semarang: Badan Penerbit Universitas Diponegoro.

Ghozali, I. (2013). Aplikasi Analisis Multivariate dengan Program IBM SPSS 21 Update PLS Regresi. Semarang: Badan Penerbit-Undip.

Goleman, D. (2000). Kecerdasan Emosional: Mengapa EQ Lebih Penting daripada IQ. Jakarta: PT. Gramedia Pustaka.

Goleman, D. (2002). Working With Emotional Intelligence. Jakarta: PT. Gramedia Pustaka.

Goodwin, R., Groth, M., \& Frenkel, S. (2011). Relationships Between Emotional Labor, Job Performance, and Turnover. Journal of Vocational Behavior, 79(2), 538-548. 
Grandey, A. A. (2000). Emotion Regulation in the Workplace: A New Way to Conceptualize Emotional Labor. Journal of Occupational Health Psychology, 5(1), 95-110. https://doi. org/10.1037//1076-8998.5.1.95

Grandey, A. A. (2003). When "The Show Must Go On": Surface Acting and Deep Acting as a Determinants of Emotional Exhaustion and PeerRated Service Delivery. Academy of Management Journal, 46(1), 86-96.

Groth, M., Hennig-thurau, T., \& Walsh, G. (2009). Customer Reactions To Emotional Labor: the Roles of Employee Acting Strategies and Customer Detection Accuracy. Academy of Management Journal, 52(5), 958-974.

Hwa, C. (2009). Exploring the Dimensionality of Emotional Labour: The Case of Malaysian Hospitality Industry. International Journal of Business Research.

Imawati, R., \& Amalia, I. (2011). Pengaruh Budaya Organisasi dan Work Engagement terhadap Kinerja Karyawan. Jurnal Al-Azhar Indonesia Seri Humanioraeri Humaniora, 1(1), 37-43.

Institutions in Saudi Arabia: A Proposed Theoretical Framework. International Journal of Business and Social Science, 4 (9), 80-95.

Jackson, L. J. (2014). The Work Engagement and Job Performance Relationship: Exploring the Mediating Effect of Trait Emotional Intelligence. Master's Theses and Graduate Research.

Joushan, S., Syamsun, M., \& Kartika, L. (2015). Pengaruh Budaya Organisasi dan Employee Engagement terhadap Kinerja Karyawan pada PT PLN ( Persero ) Area Bekasi. Jurnal Aplikasi manajemen, 13(4), 697-703

Judge, T. A., Woolf, E. F., \& Hurst, C. (2009). Is Emotional Labor More Difficult for Some Than for Others? a Multilevel, Experience-Sampling Study. Personnel Psychology; Spring ABI/INFORM Global Pg, 62, 57-88.

Karatepe, O. M. (2011). Procedural Justice, Work Engagement, and Job Outcomes: Evidence from Nigeria. Journal of Hospitality Marketing and Management, 20(8), 855-878

Keltner, D. \& Haidt, J. (1999). Social Functions of Emotions at Four Levels of Analysis. Cognition and Emotion, 13(5), 505-521.

Khanifah, S., \& Palupiningdyah. (2015). Pengaruh Kecerdasan Emosional dan Budaya Organisasi pada Kinerja dengan Komitmen Organisasi. Management Analysis Journal, 4(3), 200-211.

Kinman, G. (2008). Emotional Labour and Strain in "Front Line" Service Employee. Journal of Managerial Psychology, 24, 118-135.

Latifah \& Wulansari, N. (2017). Pengaruh Kecerdasan Emosional pada Perilaku Lalai dengan Menggunakan Persepsi Politik Organisasional sebagai Variabel Pemediasi. Management Analysis Journal, 6(3), 221-241.

Law, K. S., Wong, C., Huang, G., \& Li, X. (2008). The Effects of Emotional Intelligence on Job Performance and Life Satisfaction among Research and Development Scientists in China. Asian Pacific Journal of Management, 25 (1), 51-69.

Liu, C., Liu, X., \& Geng, Z. (2013). Emotional Labor Strategies And Service Performance: The Mediating Role of Employee Creativity. The Journal of Applied Business Research, 29(5), 15831596.

Manurung, M., Sugiarto, J., \& D., Munas B. (2016). Membangun Keunggulan Bersaing untuk Meningkatkan Kinerja Bisnis pada Industri Kecil Menengah Tenun Ikat di Troso, Jepara. Jurnal Bisnis Strategi, 25(2), 171-184.

Markos, S., \& Sridevi, M. S. (2010). Employee Engagement: The Key to Improving Performance. International Journal of Business and Management, 5(12), 89-96.

Marpaung, R. \& Rumondang, C. (2013). Pengaruh Kecerdasan Intelektual, Kecerdasan Emosi, dan Kecerdasan Spiritual terhadap Kinerja Karyawan PT. Angkasa Pura II Cabang SSK II Pekanbaru. Pekbis Jurnal, 5(3), 179-189.

Munir, M. \& Azam, R. (2017). Emotional Intelligence and Employee Performance: An Intervention Based Experimental Study. Journal of Business \& Economics, 9(2), 1-19.

Raharjo, D. C., \& Witiastuti, R. S. (2016). Pengaruh Kepemimpinan Transformasional terhadap Keterikatan Kerja melalui Keadilan Organisasional sebagai Variabel Mediasi. Management Analysis Journal, 5(4).

Ranihusna, D. (2010). Efek Rantai Motivasi Pada Kinerja Karyawan. Jurnal Dinamika Manajemen, 1(2), 90-103.

Rankin, B. (2013). Emotional Intelligence: Enhancing Values-Based Practice and Compassionate Care in Nursing. Journal of Advanced Nursing, 69, 2717-2725.

Richards, J.M., \& Gross J. J. (2000). Emotion regulation and memory: The cognitive costs of keeping one's cool. Journal of Personality and Social Psychology. 79(3), 410-24.

Rustiana, A. 2010. Efektivitas Pelatihan Bagi Peningkatan Kinerja Karyawan. Jurnal Dinamika Manajemen. 1 (2), 137-143.

Salanova, M., Agut, S., \& Peiró, J. M. (2005). Linking Organizational Resources and Work Engagement to Employee Performance and Customer Loyalty: The Mediation of Service Climate. Journal of Applied Psychology, 90(6), 1217-1227.

Sanjaya, F. 2012. Peran Moderasi Kecerdasan Emosi pada Stres Kerja. Jurnal Dinamika Manajemen. 3(2), 155-163.

Sarangi, S., \& Srivastava, R. K. (2012). Impact of Organizational Culture and Communication on Employee Engagement: an Investigation of Indian Private Banks. South Asian Journal of Management, 19(3), 18-33.

Schaufeli, W. B., \& Bakker, A. B. (2004). Job Demands, Job Resources, and Their Relationship with Burnout and Engagement: A Multi-Sample Study. Journal of Organizational Behavior, 25(3), 293-315. 
Schaufeli, W. B., Salanova, M., Gonzalez-Roma, V., \& Bakker, A. B. (2002). The Measurement of Engagement and Burnout: A Two Sample Confirmatory Factor Analytic Approach. Journal of Happiness Studies, 3, 71-92.

Sosik, J. \& Megerian, L. (1999). Understanding Leader Emotional Intelligence and Performance: The Role of Self-Other Agreement on Transformational Leadership Perceptions. Group and Organization management, 24(3), 367-390.

Sudarma, K. (2012). Mencapai Sumber Daya Manusia
Unggul (Analisis Kinerja dan Kualitas Pelayanan). Jurnal Dinamika Manajemen, 3(1), 76-83.

Susmiati \& Sudarma, K. 2015. Pengaruh Budaya Organisasi dan Dukungan Organisasi Persepsian terhadap Kinerja Karyawan dengan Komitmen Organisasi sebagai Variabel Intervening. Management Analysis Journal. 4 (1).

Wong, C., \& Law, K. S. (2002). The Effects Of Leader And Follower Emotional Intelligence On Performance And Attitude: An Exploratory Study. Asian Pacific Journal of Management, 13, 243-274. 